\title{
Penerapan Prinsip Kehati-Hatian Notaris Dalam Mengenal Para Penghadap
}

\author{
Fikri Ariesta Rahman \\ Magister Kenotaritan Fakultas Hukum Universitas Islam Indonesia \\ Jln. Cik Di Tiro No. 1 Yogyakarta \\ ellafikriani30@gmail.com
}

\begin{abstract}
The problem that is discussed in this research is the implementation of the precautionary principle of the Notary in knowing the applicant; and the legal consequences of an authentic deed which is made by the notary who has not applied the precautionary principle in knowing the applicant. This research uses a juridical-empirical approach, by analyzing a statute that applies to be used as a basis for solving problems. The informant is a notary in Yogyakarta City who is still active in the Regional Supervisory Council and Central Supervisory Council. The results of this study explain that the Notary in applying the Precautionary Principle begins with ensuring and checking the formal truth of the applicant. if it is deemed insufficient, then the notary should seek material truth, in order to achieve the goal of the precautionary principle in getting to know the parties and minimize the possibility of problems in the future. Legal consequences if the notary does not apply the precautionary principle would be, if a mistake comes from the parties towards the deed, then the deed can be degraded to a deed under the hand. If the notary who is guilty, then he or she can be held liable either administratively, civil or criminal.
\end{abstract}

Keywords: Identification and verification; notary; precautionary principle

\begin{abstract}
Abstrak
Permasalahan yang dijadikan pembahasan dalam penelitian ini yaitu penerepan prinsip kehati-hatian Notaris dalam mengenal para penghadap; dan akibat hukum atas akta autentik yang oleh Notaris tidak diterapkan prinsip kehati-hatian dalam mengenal para penghadap. Pendekatan penelitian ini merupakan penelitian yuridis-empiris. Dengan menganalisis suatu peraturan undang-undang yang berlaku untuk digunakan sebagai dasar untuk melakukan pemecahan masalah. Narasumber, yaitu Notaris di Kota Yogyakarta yang masih aktif dalam Majelis Pengawas Daerah dan Majelis Pengawas Pusat. Hasil Penelitian ini menerangkan bahwa Notaris dalam menerapkan Prinsip Kehati-hatian diawali dengan memastikan dan mengecek kebenaran formil dari penghadap. jika dinilai kurang, maka seharusnya notaris mencari kebenaran materil, demi tercapainya tujuan dari prinsip kehati-hatian dalam mengenal para penghadap dan memperkecil kemungkinan terjadi masalah dikemudian hari. Akibat hukum jika Notaris tidak menerapkan prinsip kehati-hatian yaitu jika kesalahan datang dari para penghadap terhadap aktanya, maka akta tersebut dapat didegradasi menjadi akta di bawah tangan. Jika Notaris yang bersalah dapat dimintai pertanggung jawaban baik secara administratif, perdata maupun pidana.
\end{abstract}

Kata-kata Kunci: Identifikasi dan verifikasi; notaris; prinsip kehati-hatian 


\section{Pendahuluan}

Profesi Notaris telah lama dikenal di Indonesia, bahkan jauh sebelum Indonesia merdeka yaitu pada masa pemerintahan kolonial Belanda. Pada awalnya, keberadaan Notaris merupakan suatu kebutuhan bangsa Eropa di Indonesia dalam upaya untuk menciptakan akta autentik, khususnya dalam bidang perdagangan. ${ }^{1}$

Profesi notaris populer di kalangan masyarakat, keberadaannya semakin dibutuhkan dalam membuat suatu alat bukti tertulis yang bersifat autentik dari suatu perbuatan hukum yang dilakukan oleh masyarakat. Maka tidak jarang berbagai peraturan perundang-undangan mewajibkan perbuatan hukum tertentu dibuat dalam akta autentik. Notaris dan produk aktanya dapat dimaknai sebagai upaya negara untuk menciptakan kepastian dan perlindungan hukum bagi anggota masyarakat.

Jabatan Notaris adalah sebagai pejabat umum yang ditugaskan oleh kekuasaan umum untuk melayani kebutuhan masyarakat akan alat bukti autentik yang memberikan kepastian hubungan hukum keperdataan. Sepanjang alat bukti autentik tetap diperlukan oleh sistem hukum Negara maka jabatan Notaris akan tetap diperlukan eksistensinya di tengah masyarakat. ${ }^{2}$

Akta autentik yang dibuat oleh notaris memiliki kekuatan hukum yang sangat kuat mengingat akta autentik merupakan alat bukti yang sempurna, maka tidak jarang berbagai peraturan perundangan mewajibkan peraturan hukum tertentu dibuat dalam akta autentik, seperti pendirian perseroan terbatas, koperasi, akta jaminan fidusia, dan sebagainya di samping akta tersebut dibuat atas permintaan para pihak. Hukum positif di Indonesia telah mengatur jabatan notaris dalam suatu undang- undang khusus, pemerintah bersama dengan Dewan Perwakilan Rakyat menetapkan Undang-Undang Nomor 30 Tahun 2004 tentang Jabatan Notaris. ${ }^{3}$ hlm. 2-3.

${ }^{1}$ Hartanti Silihandari \& Nisya Rifiani, Prinsip-Prinsip Dasar Profesi Notaris, Dunia Cerdas, Yogyakarta, 2013,

2 Suparman Marzuki, Etika \& Kode Etik Profesi Hukum, FH UII Press, Yogyakarta, 2017, hlm. 63.

3 Abdul Ghofur Anshori, Lembaga Kenotariatan Indonesia Prespektif Hukum dan Etika, FH UII Press Yogyakarta, 2009, hlm. 5. 
Seorang notaris dalam menjalankan jabatannya mempunyai kewenangan khusus dalam membuat akta autentik diatur dalam Pasal 15 ayat (1), Undangundang Nomor 30 Tahun 2004 sebagaimana yang telah diubah dengan UndangUndang Nomor 2 Tahun 2014 tentang Jabatan Notaris, kewenangan tersebut meliputi:4

a) Mengesahkan tanda tangan dan menetapkan kepastian tanggal surat di bawah tangan dengan mendaftar dalam buku khusus;

b) Membukukan surat di bawah tangan dengan mendaftar dalam buku khusus;

c) Membuat kopi dari asli surat di bawah tangan berupa salinan yang membuat uraian sebagaimana ditulis dan digambarkan dalam surat yang bersangkutan;

d) Melakukan pengesahan kecocokan fotokopi dengan surat aslinya;

e) Memberikan penyuluhan hukum sehubungan dengan pembuatan akta;

f) Membuat akta yang berkaitan dengan pertanahan; atau

g) Membuat akta risalah lelang.

Pasal 16 Undang-Undang Nomor 2 Tahun 2014 Tentang Jabatan Notaris ayat (1) huruf (a) dalam menjalankan jabatannya, notaris wajib bertindak amanah, jujur, saksama, mandiri, tidak berpihak dan menjaga kepentingan pihak yang terkait dalam perbuatan hukum. Makna "saksama" dalam pasal ini dapat diartikan (teliti, cermat dan hati-hati), dalam menjalankan tugas haruslah hati-hati begitu pun halnya dalam mengenal para penghadap.

Notaris dalam melakukan suatu tindakan hukum harus senantiasa bertindak secara hati-hati agar notaris sebelum membuat akta, harus meneliti semua fakta yang relevan dalam pertimbangannya berdasarkan kepada perundang-undangan yang berlaku. Meneliti semua kelengkapan dan keabsahan alat bukti atau dokumen yang diperlihatkan kepada notaris, serta mendengar keterangan atau pernyataan para penghadap wajib dilakukan sebagai dasar pertimbangan untuk dituangkan di dalam akta. Apabila notaris kurang teliti dalam memeriksa faktafakta peting, itu berarti notaris bertindak tidak hati- hati.

${ }^{4}$ M. Luthfan Hadi Darus, Hukum Notariat dan Tanggung Jawab Jabatan Notaris, FH UII Press, Yogyakarta, 2017, hlm. 25. 
Notaris dalam menjalankan tugasnya harus profesional, yaitu menjalankan tugas selalu mengutamakan keahlian berlandasan kode etik dan ketentuan peraturan perundang-undangan yang berlaku, kinerjanya dapat dipercaya dan amanah, bekerja sesuai Standar Operasional Prosedural (SOP) dari memulai pekerjaan, menjalankan dan menghasilkan hasil yang akurat. Selain profesional, notaris juga harus mampu memberikan penyuluhan hukum yang tepat dan baik untuk para penghadap.

Akta notaris harus memberikan kepastian bahwa sesuatu kejadian dan fakta tersebut dalam akta betul-betul dilakukan oleh Notaris atau diterangkan oleh pihak-pihak yang menghadap pada saat yang tercantum dalam akta sesuai dengan prosedur yang sudah ditentukan dalam pembuatan akta. Secara formal untuk membuktikan kebenaran dan kepastian tentang hari, tanggal, bulan, tahun, waktu menghadap, dan para pihak yang menghadap, paraf dan tanda tangan para penghadap, saksi dan Notaris, serta membuktikan apa yang dilihat, disaksikan, didengar oleh Notaris (pada akta pejabat atau berita acara), dan mencatatkan keterangan atau pernyataan para penghadap (pada akta pihak). ${ }^{5}$

Namun demikian, terlepas dari kejujuran, ketelitian dan ketidakberpihakan dari segi notaris, dokumen palsu dan keterangan palsu dari para penghadap masih tetap menjadi permasalahan dan ancaman bagi Notaris tersebut. Meskipun Notaris tidak bertanggungjawab atas dokumen palsu dan keterangan palsu yang dibuat oleh para penghadap, akan tetapi, hal ini tetap dapat merugikan Notaris. Bahkan, bukan tidak mungkin hal tersebut menjadi celah pidana bagi sang Notaris. Ketika terjadi sengketa Notaris akan dipanggil dan dimintai keterangan sebagai saksi. Tidak sedikit waktu dan kerugian secara materi yang akan dihabiskan. Hal ini menjadi topik yang menarik untuk dikaji, terkait dampak bagi Notaris yang bersangkutan atas dokumen palsu dan keterangan palsu yang diberikan oleh para penghadap tersebut, yang kemudian merujuk kepada pentingnya bagi Notaris dalam menerapkan prinsip kehati-hatian dalam mengenal para penghadap. Berangkat dari pemikiran tersebut, penulis bermaksud untuk memaparkan pembahasannya di dalam tulisan ini.

${ }^{5}$ Habib Adjie, Kebatalan Dan Pembatalan Akta Notaris, Refika Aditama, Surabaya, 2010, hlm. 19. 


\section{Rumusan Masalah}

Berdasarkan pendahuluan di atas maka rumusan masalah yang dikemukakan dalam penelitian ini, pertama, bagaimana penerapan prinsip kehati-hatian Notaris dalam mengenal para penghadap? Kedua, bagaimana akibat hukum atas akta autentik yang oleh Notaris tidak diterapkan prinsip kehati-hatian dalam mengenal para penghadap?

\section{Tujuan Penelitian}

Adapun tujuan dari penelitian ini ialah untuk memahami bagaimana Notaris menerapkan prinsip kehati-hatian dalam mengenal para penghadap serta akibat hukum atas akta autentik yang tidak menerapkan prinsip kehati-hatian dalam mengenal para penghadap.

\section{Metode Penelitian}

Penulis menggunakan metode penelitian kepustakaan (library research) yang bersifat yuridis empiris adalah metode penelitian dengan mengkaji dan meneliti data sekunder terlebih dahulu yang kemudian dilanjutkan dengan data primer yang diperoleh dari lapangan. Objek penelitian yang akan di teliti oleh penulis adalah Studi Pustaka dan Lapangan dan Subjek penelitian yang akan di teliti oleh penulis adalah notaris, Majelis Pengawas Daerah Notaris dan Majelis Pengawas Pusat Notaris. Bahan hukum Primer yaitu Undang-Undang Nomor 2 Tahun 2014 Tentang Jabatan Notaris. Bahan hukum sekunder yaitu berupa literatur yang berhubungan dengan obyek penelitian, seperti buku- buku yang ditulis para ahli hukum, doktrin, pendapat maupun ajaran dari para ahli hukum, jurnal- jurnal hukum, karya ilmiah, dan materi dari internet. Bahan hukum tersier yaitu berupa kamus untuk memahami kata- kata yang kurang jelas dalam istilah hukum maupun istilah lain. Pihak-pihak yang akan diwawancarai. Data yang diperoleh melalui studi kepustakaan, dan pengamatan diproses secara identifikasi, sistematis, dan analisis. Sesuai dengan metode pendekatan yuridis empiris yang menekankan pada data primer, maka strategi atau pendekatan yang digunakan dalam menganalisis data adalah metode analisis kualitatif. Analisa kualitatif yang 
digunakan bersifat deskriptif dan perspektif, yaitu akan berusaha memberikan data yang ada dan menilainya kemudian menganalisis masalah-masalah yang ada yang berkaitan dengan penerapan implementasi pertanggung jawaban notaris di Yogyakarta. Serta memberikan solusi untuk mengatasi masalah- masalah tersebut.

\section{Hasil Penelitian dan Pembahasan}

\section{Penerapan Prinsip Kehati-hatian Notaris dalam Mengenal Para Penghadap}

Jabatan Notaris merupakan jabatan kepercayaan yang harus selaras dengan mereka yang menjalankan tugas jabatan notaris sebagai orang yang dipercaya. Notaris sebagai jabatan yang kepercayaan tidak berarti apa-apa jika ternyata mereka menjalankan tugas jabatan sebagai notaris adalah orang yang tidak dapat dipercaya. Dalam hal ini, antara jabatan notaris dan pejabatnya (yang menjalankan tugas jabatan notaris) harus sejalan bagaikan dua sisi mata uang yang tidak dapat dipisahkan. ${ }^{6}$

Jabatan notaris atau kehadirannya dikehendaki oleh aturan hukum dengan maksud untuk membantu dan melayani masyarakat yang membutuhkan alat bukti tertulis yang bersifat autentik mengenai keadaan peristiwa atau perbuatan hukum. Dengan dasar seperti ini mereka yang diangkat sebagai notaris harus mempunyai semangat untuk melayani masyarakat, dan atas pelayanan tersebut, masyarakat yang telah merasa dilayani oleh notaris sesuai dengan tugas jabatannya, dapat memberikan honorarium kepada notaris. Oleh karena itu notaris tidak berarti apaapa jika masyarakat tidak membutuhkannya.

Asas kehati-hatian adalah suatu asas yang menyatakan bahwa notaris dalam menjalankan fungsi dan jabatannya wajib menerapkan prinsip kehati-hatian dalam rangka melindungi kepentingan masyarakat yang dipercayakan padanya. Tujuan diberlakukannya prinsip kehati-hatian tidak lain adalah agar notaris selalu dalam rambu-rambu yang benar. Dengan diberlakukannya prinsip kehati-hatian diharapkan agar kepercayaan masyarakat terhadap notaris tetap tinggi, sehingga masyarakat bersedia dan tidak ragu-ragu menggunakan jasa notaris. Sesuatu perbuatan harus diambil dan disusun dengan pertimbangan cermat.

${ }^{6}$ Habib Adjie, Sanksi Perdata dan Administratif Terhadap Notaris Sebagai Pejabat Publik, Refika Aditama, Bandung, 2009, hlm. 83. 
Permasalahan hukum pidana dalam praktik kenotariatan disebabkan karena kurangnya kehati-hatian notaris dalam membuat akta autentik terhadap data para pihak terkait subyek ataupun obyek yang dibawa oleh para pihak untuk membuat akta autentik sehingga menyebabkan sering terjadinya tindak kejahatan seperti dokumen palsu atau keterangan palsu yang dilakukan oleh para pihak dalam akta autentik yang dibuat oleh notaris.

Notaris dalam menjalankan tugas dan jabatannya sangat penting untuk melaksanakan prinsip kehati-hatian dalam proses pembuatan akta autentik, mengingat seringnya terjadi permasalahan hukum terhadap akta autentik yang dibuat notaris karena terdapat pihak-pihak yang melakukan kejahatan seperti memberikan surat palsu dan keterangan palsu ke dalam akta yang dibuat notaris. Sehingga untuk mencegah terjadinya kejahatan-kejahatan yang dapat menjerumuskan notaris terlibat dalam permasalahan hukum, perlu diatur kembali dalam Undang-Undang Jabatan Notaris tentang pedoman dan tuntunan notaris untuk bertindak lebih cermat, teliti dan hati-hati dalam proses pembuatan akta autentik.

Bentuk-bentuk prinsip kehati-hatian (prudentiality principle) yang seharusnya dilakukan notaris dalam proses pembuatan akta yaitu, melakukan pengenalan terhadap identitas penghadap, memverifikasi secara cermat data subyek dan obyek penghadap, memberi tenggang waktu dalam pengerjaan akta, bertindak hati-hati, cermat dan teliti dalam proses pengerjaan akta, memenuhi segala teknik syarat pembuatan akta dan melaporkan apabila terjadi indikasi pencucian uang (money laundering) dalam transaksi di notaris, bentuk-bentuk prinsip kehati-hatian seperti ini sudah seharusnya wajib dilaksanakan notaris agar nantinya notaris dapat mencegah timbulnya permasalahan hukum terhadap akta autentik yang dibuatnya dikemudian hari. ${ }^{7}$

Notaris dan para pihak agar terhindar dari segala risiko baik berupa sanksi maupun pembatalan akta autentik maka dalam proses pembuatan akta autentik di

${ }^{7}$ Ida Bagus Paramaningrat Manuaba, Prinsip Kehati-hatian Notaris dalam Membuat Akta Autentitk, tesis, Program Magister Kenotariatan Fakultas Hukum Universitas Udayana, 2017. 
hadapan Notaris maka Notaris dan para pihak harus melaksanakan prinsip kehatihatian dengan cara lebih teliti dan memiliki itikad baik dalam pembuatan akta autentik serta mematuhi ketentuan hukum yang berlaku dan berlandaskan pada moral dan etika.

Dalam wawancara pertama, ${ }^{8}$ penulis bertemu langsung dengan Notaris dan Anggota Majelis Pengawas Notaris Daerah Yogyakarta Dyah Maryulina Budi Mumpuni, S.H., M.H. Jalan Gondosuli No. 14 Semaki, Umbulharjo, Kota Yogyakarta, Daerah Istimewa Yogyakarta, mengatakan bahwa Penerapan Prinsip Kehati-Hatian Notaris Dalam Mengenal Para Penghadap dimulai dari Memberikan Penyuluhan Hukum dan Edukasi Hukum kepada para penghadap. Menuangkan keinginan para penghadap dalam akta autentik, dalam pembuatan akta tidak boleh bertentangan dengan aturan yang belaku, semua persyaratan harus dipenuhi oleh para penghadap, kemudian harus diteliti, diperiksa, melakukan pengecekan dokumen dengan instansi yang terkait. Mengecek langsung secara online dokumen ke sistem instansi pemerintahan. Seperti dalam hal mengecek Kartu Identitas Penduduk melalui sistem online Dinas Kependudukan dan Catatan Sipil.

Menanyakan dan mencocokkan langsung kebenaran biodata, seperti tanggal dan alamat di dalam Kartu Tanda Penduduk kepada para penghadap. Cara tersebut merupakan salah satu cara untuk menerapkan prinsip kehati-hatian dalam mengenal para penghadap. Jika yang menghadap bukan merupakan penghadap yang sesuai di dalam Kartu Tanda Penduduk, maka akan terlihat secara fisik dan perilaku yang dapat dilihat langsung ada kejanggalan dan perbedaan.

Berilmu, Integritas dan Profesionalitas merupakan hal yang harus dimiliki Notaris, Notaris harus paham semua perbuatan hukum yang diinginkan oleh para penghadap. Memiliki kemampuan dan ilmu dalam bidang hukum, ketika notaris tidak memahami perbuatan hukum yang akan diinginkan para penghadap, maka Notaris tersebut tidak paham akan keilmuan yang harus dimilikinya. Apabila Notaris memiliki kemampuan dalam hal perbuatan hukum yang diinginkan para penghadap, memperkecil risiko kerugian dan sengketa yang akan dialami para penghadap atau Notaris sendiri.

${ }^{8}$ Hasil wawancara dengan Notaris Kota Yogyakarta, pada hari Rabu tanggal 19 September 2018, pukul 12:00 WIB. 
Para Penghadap sudah memenuhi semua syarat formiil maka itu cukup menjadi dasar Notaris untuk melakukan perbuatan hukum yang diinginkan para penghadap. Notaris tidak dibebani untuk mencari kebenaran secara materiil, tetapi ketika ada keraguan dan keanehan dari dokumen-dokumen yang menjadi syarat untuk pembuatan akta para penghadap. Maka notaris hendaknya mencari kebenaran secara materiil atas dokumen penghadap. Demi tercapainya prinsip kehati-hatian Notaris dalam mengenal para penghadap. Jika terdapat keraguan dan kesalahan atas dokumen-dokumen para penghadap Notaris sebaiknya menolak untuk membuat akta autentik, untuk tercapainya prinsip kehati-hatian mengenal para penghadap dan tidak menjadi sengketa dikemudian hari.

Dalam wawancara kedua, penulis bertemu langsung dengan Notaris dan Majelis Pengawas Notaris Pusat Hendrik Budi Untung, S.H., M.M., ${ }^{9}$ Jalan Suharto No. 2, Kota Baru, Gondokusumna, Kota Yogyakarta, Daerah Istimewa Yogyakarta, mengatakan bahwa penerapan prinsip kehati-hatian notaris dalam mengenal para penghadap diawali dengan setiap pembuatan akta harus selalu meminta warkah aslinya, kemudian disesuaikan dengan perbuatan hukum yang akan dilakukan, akibat hukum dan solusinya. Kemudian melakukan pengecekan dan pencocokan dokumen-dokumen yang diperlihatkan penghadap. Melakukan perbuatan hukum dalam hal pembuatan akta sesuai dengan standar operasional Notaris, melakukan pembuatan sesuai dengan prosedur-prosedur yang belaku.

Menurut Heri, ${ }^{10}$ dalam membuat akta notaris harus berpegang pada prinsip kehati-hatian seorang notaris (prudent notarius principle), tidak melampaui batas kewenangan (ultra vires), prinsip mengenal klien (Know Your Customer), dan mengidentifikasi dokumen berupa penulisan, isi, legalitas (identify for validity). Memang bukan tugas notaris memastikan kebenaran materiil dari data yang diajukan penghadap. Namun bukan serta merta notaris tidak melakukan tindakan kehati-hatian untuk menghindari kelalaian. Ia mencontohkan soal antisipasi KTP

\footnotetext{
${ }^{9}$ Hasil wawancara dengan Notaris Kota Yogyakarta, pada hari Kamis tanggal 20 September 2018, pukul 13:00 WIB.

10 "Waspadai Tuntutan Pidana yang Mungkin Dihadapi Notaris dalam Bertugas" https://www.hukumonline.com/berita/baca/lt5a7ae033bc871/waspadai-tuntutan-pidana-yang-mungkindihadapi-notaris-dalam-bertugas, diakses tanggal 23 September 2018.
} 
palsu. Notaris perlu teliti mengetahui soal nomor penanda wilayah dalam standar Nomor Induk Kependudukan. "Ini KTP umpamanya di Bogor, kok beda kode NIK, Bogor misalnya 352, kok ini 351," katanya.

Nesia Zara Ferina, ${ }^{11}$ Penggunaan sidik jari penghadap yang dilekatkan pada minuta akta sebagaimana yang disebutkan dalam Pasal 16 ayat (1) huruf c Undang Undang Nomor 2 Tahun 2014 tentang Jabatan Notaris memiliki maksud untuk menghindarkan penyangkalan-penyangkalan mengenai kehadiran dan tanda tangan yang dilakukan oleh penghadap. Tujuannya ialah dalam rangka mewujudkan prinsip kehati-hatian Notaris agar sidik jari tersebut sebagai back-up apabila keduanya telah diingkari. Apabila sidik jari ini tidak ada maka akta tidak kehilangan autensitasnya. Karena bukan merupakan bagian minuta akta maka lembar sidik jari ini terpisah dari minuta akta dan hanya merupakan warkah pendukung. Walaupun tidak berakibat pada aktanya, sewajarnya Notaris tetap menjalankan amanat Undang-Undang ini karena Notaris merupakan pejabat umum yang telah disumpah untuk tunduk pada ketentuan dalam UUJN dan Kode Etik Notaris. Pelaksanaan penggunaan sidik jari tergantung penafsiran dari masing-masing Notaris.

\section{Akibat Hukum atas Akta Autentik yang Tidak Menerapkan Prinsip Kehati- Hatian Notaris dalam Mengenal Para Penghadap}

Notaris dalam menjalankan tugas dan jabatannya dalam membuat akta tidak luput dari kesalahan atau kekeliruan baik yang disebabkan karena perilaku yang tidak profesional atau memihak salah satu pihak sehingga terjadi permasalahan dalam akta yang dibuatnya. Sebagai pejabat umum yang berwenang untuk membuat akta autentik Notaris seringkali bertindak tidak hati-hati yang berakibat menimbulkan permasalahan hukum, baik dalam ranah hukum pidana maupun ranah hukum perdata, ini disebabkan karena para pihak yang membuat akta autentik memberikan dokumen palsu ataupun memberikan keterangan palsu kepada notaris sehingga menimbulkan permasalahan hukum terhadap akta autentik yang dibuatnya.

${ }^{11}$ Nesia Zara Ferina, Telaah Penggunaan Sidik Jari Penghadap Yang Dilekatkan Pada Minuta Akta Pasca Revisi Undang-Udang Jabatan Notaris, tesis Magister Kenotariatan Universitas Gajah Mada, 2014, hlm. 80. 
Tanggung jawab (responsibility) merupakan suatu refleksi tingkah laku manusia. Penampilan tingkah laku manusia terkait dengan kontrol jiwanya, merupakan bagian dari bentuk pertimbangan intelektual atau mentalnya. Bilamana suatu keputusan telah diambil atau ditolak, sudah merupakan bagian dari tanggung jawab dan akibat pilihannya. Tidak ada alasan lain mengapa hal itu dilakukan atau ditinggalkan. Keputusan tersebut dianggap telah dipimpin oleh kesadaran intelektualnya. ${ }^{12}$

Apabila terjadi pelanggaran terhadap Pasal 16 ayat (1) (a) secara profesional notaris yang bersangkutan harus bertanggung jawab atas tidak sempurnanya akta yang dibuat. Bermacam-macam bentuk tanggung jawab dari seorang notaris dalam melaksanakan tugas dan jabatannya ternasuk tanggung jawab secara moral.

Permasalahan berpotensi pemidanaan yang sering terjadi dalam tugas Notaris di antaranya:

1. Akta dibuat dengan kondisi para pihak tidak berhadapan;

2. Data identitas dari salah satu pihak dalam akta dianggap tidak benar atau dianggap memberikan keterangan palsu;

3. Data mengenai obyek yang diperjanjikan tidak sesuai dengan fakta yang sebenarnya;

4. Data yang diberikan oleh salah satu atau kedua pihak tidak benar, sehingga akta notaris yang diterbitkan dianggap akta palsu;

5. Ada dua akta yang beredar di para pihak, yang nomor dan tanggalnya sama tetapi isinya berbeda;

6. Tanda tangan salah satu pihak yang ada dalam minuta dipalsukan; atau

7. Penghadap menggunakan identitas orang lain. ${ }^{13}$

Notaris yang melakukan kesalahan di dalam menjalankan tugas jabatannya tidak dapat lepas dari sanksi-sanksi yang ada. Sanksi dapat berupa sanksi pidana maupun sanksi perdata. Perdata berlaku atas akta yang dibuat oleh Notaris kehilangan sifatnya sebagai akta Notaris, akta kehilangan keauntetikannya.

Hasil wawancara, pertama, peneliti bertemu langsung dengan Notaris dan Anggota Majelis Pengawas Notaris Daerah Yogyakarta Dyah Maryulina Budi

\footnotetext{
12 Masyur Efendi, Dimensi/Dinamika Hak Asasi Manusia Dalam Hukum Nasional Dan Internasional, Ghalia Indonesia, Jakarta, 1994, hlm. 82.

13 "Waspadai Tuntutan Pidana yang Mungkin Dihadapi Notaris dalam Bertugas" https://www.hukumonline.com/berita/baca/lt5a7ae033bc871/waspadai-tuntutan-pidana-yang-mungkindihadapi-notaris-dalam-bertugas, diakses tanggal 23 September 2018.
} 
Mumpuni, S.H., M.H.14 Jalan Gondosuli No. 14 Semaki, Umbulharjo, Kota Yogyakarta, Daerah Istimewa Yogyakarta, mengatakan bahwa akibat hukum notaris tidak menerapkan prinsip kehati-hatian dalam mengenal para penghadap yaitu harus dilihat dari perbuatan hukumnya terlebih dahulu, Kesalahan datang dari penghadap seperti pemalsuan dokumen dan yang hadir bukan penghadap sesungguhnya, Notaris tidak bertanggung jawab untuk hal itu. Hal tersebut merupakan tanggung jawab dari pihak penghadap sendiri. Sedangkan jika kesalahan itu datang dari Notaris, maka dapat dimintakan pertanggungjawaban secara perdata dan pidana. Terhadap aktanya dapat didegradasi menjadi akta di bawah tangan.

Hasil wawancara, kedua, peneliti bertemu langsung dengan Notaris dan Majelis Pengawas Notaris Pusat Hendrik Budi Untung, S.H., M.M., ${ }^{15}$ Jalan Suharto No. 2, Kota Baru, Gondokusuma, Kota Yogyakarta, Daerah Istimewa Yogyakarta, mengatakan bahwa akibat hukum notaris tidak menerapkan prinsip kehati-hatian dalam mengenal para penghadap yaitu melihat terlebih dahulu perbuatan hukum yang akan dilakukan oleh para penghadap. Jika yang mengatakan hadir bukan orang yang sesungguhnya menghadap ke kantor Notaris, maka aktanya dapat didegradasi. Notaris tidak bertanggungjawab terhadap dokumen palsu dan kekeliruan yang diperlihatkan oleh penghadap.

Akta autentik menjadi degradasi menjadi akta di bawah tangan yaitu akta autentik mengalami penurunan mutu atau kemunduran atau kemerosotan status, dalam arti posisinya lebih rendah dalam kekuatan sebagai alat bukti, dari kekuatan bukti lengkap dan sempurna menjadi permulaan pembuktian seperti akta di bawah tangan dan dapat memiliki cacat hukum yang menyebabkan kebatalan atau ketidakabsahannya akta tersebut.

Perbedaan degradasi dengan pembatalan akta autentik adalah jika dinyatakan batal oleh hakim, maka akta autentik dinyatakan tidak perdah ada. akibat hukum perlu dibedakan antara dinyatakan dapat dibatalkan yaitu syarat

${ }^{14}$ Hasil wawancara dengan Notaris Kota Yogyakarta, pada hari Kamis tanggal 20 September 2018, pukul 13:00 WIB.

${ }^{15}$ Hasil wawancara dengan Notaris Kota Yogyakarta, pada hari Kamis tanggal 20 September 2018, pukul 13:00 WIB. 
subyektif yang dinyatakan tidak sah atau batal demi hukum yaitu syarat objektif yang dinyatakan tidak sah.

Akta Notaris Batal Demi Hukum yaitu akibatnya perbuatan hukum yang dilakukan tidak mempunyai akibat sejak terjadinya hukum tersebut atau surut, batal demi hukum didasarkan pada Putusan Pengadilan yang telah mempunyai kekuatan hukum tetap. Sedangkan dapat dibatalkan akibatnya perbuatan hukum yang dilakukan tidak mempunyai akibat hukum sejak terjadinya pembatalan dan di mana pembatalan atau perbuatan hukum tersebut tergantung pada pihak tertentu, yang menyebabkan perbuatan hukum tersebut dapat dibatalkan. Akta yang sanksinya dapat dibatalkan, tetap berlaku dan mengikat selama belum ada putusan pengadilan yang telah mempunyai kekuatan hukum tetap yang membatalkan akta tersebut.

Notaris yang melakukan kesalah dalam mengenal identitas para penghadap yaitu kepatutan, ketelitian dan sikap hati-hati mewajibkan setiap orang dalam memenuhi kepentingannya memperhatikan kepentingan orang lain. Pemenuhan kepentingan seseorang haruslah dilaksanakan sedemikian rupa, sehingga tidak berbahaya bagi kepentingan para penghadap. Notaris yang merugikan, misalnya membuat akta yang tidak melindungi hak-hak para pengahadap sebagaimana yang ada dalam akta notaris. Sanksinya yaitu hilangnya kepercayaan terhadap Notaris tersebut, sedangkan sanksi pelanggaran hukum yang dilakukan Notaris jika ada para penghadap yang melakukan gugatan maka tergantung dengan putusan hakim. Jika ada salah satu para penghadap dirugikan karena kesalahan dan kelalaian Notaris, maka penghadap dapat meminta ganti rugi.

Upaya hukum yang dapat dilakukan oleh Pihak yang dirugikan akibat ketidakcermatan Notaris: 16

1. Apabila ada pihak yang merasa dirugikan akibat ketidakcermatan notaris dalam menjalankan jabatannya maka pihak tersebut dapat menuntut ganti rugi, biayabiaya, dan bunga dengan mengajukan gugatan ke pengadilan negeri.

${ }^{16}$ Bayu Rushadian Hutama, Ketidak Cermatan Notaris Dalam Menjalankan Jabatan Notaris, tesis, Magister Kenotariatan Universitas Indonesia, 2012, hlm. 79-81. 
2. Upaya hukum lainnya yaitu melaporkan ke Majelis Pengawas Daerah agar Notaris yang bersangkutan dikenakan sanksi.

Proses penjatuhan sanksi. Proses penjatuhan sanksi terhadap Notaris yang terkena sanksi hukum adalah dengan mengajukan gugatan kepada pengadilan negeri. Proses penjatuhan sanksi terhadap Notaris yang terkena sanksi etika dalam Pasal 9 Kode Etik adalah sebagai berikut:

a) Apabila ada anggota yang diduga melakukan pelanggaran terhadap kode etik, baik dugaan tersebut berasal dari pengetahuan Dewan Kehormatan Daerah sendiri maupun karena laporan dari pengurus daerah ataupun pihak lain kepada Dewan Kehormatan Daerah, maka selambat-lambatnya dalam waktu tujuh (7) hari kerja Dewan Kehormatan Daerah wajib segera mengambil tindakan dengan mengadakan sidang dewan kehormatan daerah untuk membicarakan dugaan terhadap pelanggaran tersebut.

b) Apabila menurut hasil sidang Dewan Kehormatan Daerah sebagaimana tercantum dalam ayat (1) ternyata ada dugaan kuat terhadap pelanggaran kode etik, maka dalam waktu tujuh (7) hari kerja setelah tanggal sidang tersebut Dewan Kehormatan Daerah berkewajiban memanggil anggota yang diduga melanggar tersebut dengan surat tercatat atau dengan ekspedisi, untuk didengar keterangannya dan diberi kesempatan untuk membela diri.

c) Dewan kehormatan daerah baru akan menentukan putusannya mengenai terbukti atau tidaknya pelanggaran kode etik serta penjatuhan sanksi terhadap pelanggarnya (apabila terbukti), setelah mendengar keterangan dan pembelaan diri dari anggota yang bersangkutan dalam sidang Dewan Kehormatan Daerah.

d) Penentuan putusan tersebut dalam ayat 3 dapat dilakukan oleh Dewan Kehormatan Daerah baik dalam sidang itu maupun dalam sidang lainnya, sepanjang penentuan keputusan melanggar atau tidak melanggar tersebut, dilakukan selambat-lambatnya dalam waktu 15 hari kerja, setelah tanggal sidang Dewan Kehormatan Daerah di mana Notaris tersebut telah didengar keterangan dan/atau pembelaannya.

e) Bila dalam putusan sidang Dewan Kehormatan Daerah dinyatakan terbukti ada pelanggaran kode etik, maka sidang sekaligus menentukan sanksi terhadap pelanggarnya.

f) Dalam hal anggota yang dipanggil tidak datang atau tidak memberi kabar apa pun dalam waktu (7) hari kerja setelah dipanggil, maka Dewan Kehormatan Daerah akan mengulang panggilannya sebanyak 2 kali dengan jarak waktu (7) hari kerja, untuk setiap panggilannya.

g) Dalam waktu tujuh (7) hari kerja, setelah panggilan ke tiga (3) ternyata masih juga tidak datang atau tidak memberi kabar dengan alasan apa pun, maka Dewan Kehormatan Daerah akan tetap bersidang untuk membicarakan pelanggaran yang diduga dilakukan oleh anggota yang dipanggil itu dan 
menentukan putusannya, selanjutnya secara mutatis mutandis berlaku ketentuan dalam ayat (5) dan ayat (6) di atas serta ayat

h) Terhadap sanksi pemberhentian sementara (schorsing) atau pemecatan (onzetting) dari keanggotaan perkumpulan diputuskan, Dewan Kehormatan Daerah wajib berkonsultasi terlebih dahulu dengan pengurus daerahnya.

i) Putusan sidang Dewan Kehormatan Daerah wajib dikirim oleh Dewan Kehormatan Daerah kepada anggota yang melanggar dengan surat tercatat atau dengan ekspedisi dan tembusannya kepada Pengurus Cabang, Pengurus Daerah, Pengurus Pusat, dan Dewan Kehormatan Pusat, semuanya itu dalam waktu tujuh (7) hari kerja, setelah dijatuhkan putusan oleh sidang Dewan Kehormatan Daerah.

j) Apabila pada tingkat kepengurusan daerah belum dibentuk Dewan Kehormatan Daerah, maka Dewan Kehormatan Wilayah berkewajiban dan mempunyai wewenang untuk menjalankan kewajiban serta kewenangan Dewan Kehormatan Daerah dalam rangka penegakan kode etik atau melimpahkan tugas kewajiban dan kewenangan Dewan Kehormatan Daerah kepada kewenangan Dewan Kehormatan Daerah terdekat dari tempat kedudukan atau tempat tinggal anggota yang melanggar kode etik tersebut. Hal tersebut berlaku pula apabila Dewan Kehormatan Daerah tidak sanggup menyelesaikan atau memutuskan permasalahan yang dihadapinya.

\section{Penutup}

Berdasarkan pengambilan data dan atas pembahasan di atas dapat disimpulkan penerapan prinsip kehati-hatian notaris dalam mengenal para penghadap sebagai berikut. Pertama, Notaris melakukan pengenalan terhadap identitas penghadap, memverifikasi secara cermat data subyek dan obyek penghadap, melakukan pengecekan dokumen dengan instansi yang terkait, mengecek langsung secara online dokumen ke sistem instansi pemerintahan. Seperti dalam hal mengecek Kartu Identias Penduduk melalui sistem online Dinas Kependudukan dan Catatan Sipil, melakukan wawancara langsung kebenaran identitas kepada para penghadap, akan terlihat penghadap benar atau tidak dalam menjawab kebenaran dari identitas para penghadap.

Ketika dokumen para penghadap sebagai syarat formil untuk melakukan pembuatan akta sudah terpenuhi, Notaris menemukan keraguan dan kecurangan para penghadap sudah seharusnya Notaris mencari kebenaran materil untuk 
mencegah terjadinya permasalahan dan merugikan salah satu para penghadap. Notaris mencari kebenaran materil adalah salah satu cara Notaris menerapkan prinsip kehati-hatian dalam mengenal para penghadap dan mengecilkan kemungkinan terjadi permasalahan dikemudian hari, Memberikan penyuluhan hukum tentang akibat hukum jika penghadap memberikan keterangan palsu.

Terkait dengan Peraturan Menteri Hukum Dan Hak Asasi Manusia Nomor 9 Tahun 2017 tentang Penerapan Prinsip Mengenali Pengguna Jasa Bagi Notaris yaitu Notaris wajib menerapkan prinsip mengenali Pengguna Jasa yang paling sedikit memuat identifikasi Pengguna Jasa, verifikasi Penggena Jasa dan pemantauan Transaksi Pengguna Jasa. Peraturan ini masih menjadi problematika di lapangan untuk para Notaris untuk menjalankan peraturan ini. Notaris berpendapat bahwa Notaris tidak bertanggung jawab atas kebenaran materiil dari apa yang diperjanjikan oleh Para Pihak. Dari hasil penelitian lapangan yang dilakukan penulis belum ada sosialisasi dari Organisasi Ikatan Notaris Indonesia dan Majelis Pengawas Notaris.

Kedua, akibat hukum terhadap akta Notaris yang tidak menerapkan prinsip kehati-hatian dalam mengenal para penghadap dilakukan dengan cara melihat perbuatan hukumnya terlebih dahulu, apabila kesalahan datang dari para penghadap, akibat hukum terhadap aktanya dapat Terdegradasi menjadi akta di bawah tangan. Jika dalam proses pembuatan akta kesalahan dilakukan oleh penghadap dan bertentangan dengan aturan hukum yang berlaku, maka akta autentik tersebut dapat batal demi hukum dan dapat dibatalkan melalui putusan hakim. Sedangkan akibat hukum Notaris yang terbukti tidak menerapkan prinsip kehati-hatian dalam mengenal para penghadap yaitu dapat dikenakan sanksi administratif sesuai Undang-Undang Jabatan Notaris dan bisa dikenakan sanksi perdata seperti ganti rugi maupun sanksi pidana seperti hukuman penjara, jika memang notaris terbukti melakukan kesalahan maka salah satu penghadap yang dirugikan dapat meminta pertanggunganjawaban secara perdata yaitu ganti rugi, yang kemudian dapat meminta pertanggungjawaban secara pidana melalui putusan pengadilan dan para penghadap dapat meminta ganti kerugian. 
Adapun saran-saran yang dapat diberikan berdasarkan kesimpulan di atas terhadap penerapan prinsip kehati-hatian Notaris dalam mengenal para penghadap adalah sebagai berikut:

Pertama, Notaris dalam hal mencari kebenaran materil terhadap identitas para penghadap tidak dibebankan oleh Undang-Undang Jabatan Notaris kepada Notaris, Akan tetapi untuk menerpakan prinsip kehati-hatian dalam mengenal para penghadap. Sebaiknya Notaris mencari kebenaran materil, supaya akta yang dibuat tidak menjadi akta yang menjadi permasalahan dan merugikan para penghadap dikemudian hari.

Kedua, Notaris sebagai pejabat publik yang melaksanakan tugas mulia membantu masyarakat, dalam proses pembuatan akta Notaris memberikan penyuluhan hukum terhadap para penghadap mengenai akibat-akibat hukum dan tanggungjawab atas data, identitas, isi dokumen yang dibawa para penghadap. Menyampaikan akibat hukum jika para penghadap melakukan atau memberikan keterangan palsu terhadap identitas, kemudian Notaris haruslah bertindak cermat, teliti dan hati-hati.

\section{Daftar Pustaka}

\section{Buku}

Adjie, Habib, Kebatalan Dan Pembatalan Akta Notaris, Refika Aditama, Surabaya, 2010.

Adjie, Habib, Sanksi Perdata dan Administratif Terhadap Notaris Sebagai Pejabat Publik, Refika Aditama, Bandung, 2009.

Anshori, Abdul Ghofur, Lembaga Kenotariatan Indonesia Prespektif Hukum dan Etika, FH UII Press, Yogyakarta, 2009.

Darus, M. Luthfan Hadi, Hukum Notariat dan Tanggung Jawab Jabatan Notaris, FH UII Press, Yogyakarta, 2017.

Efendi, Masyur, Dimensi/Dinamika Hak Asasi Manusia Dalam Hukum Nasional Dan Internasional, Ghalia Indonesia, Jakarta, 1994.

Marzuki, Suparman, Etika \& Kode Etik Profesi Hukum, FH UII Press, Yogyakarta, 2017.

Silihandari, Hartanti \& Nisya Rifiani, Prinsip-Prinsip Dasar Profesi Notaris, Dunia Cerdas, Yogyakarta, 2013. 


\section{Tugas Akhir}

Hutama, Bayu Rushadian, Ketidak Cermatan Notaris Dalam Menjalankan Jabatan Notaris, tesis, Magister Kenotariatan Universitas Indonesia, Jakarta, 2012.

Ferina, Nesia Zara, Telaah Penggunaan Sidik Jari Penghadap Yang Dilekatkan Pada Minuta Akta Pasca Revisi Undang-Udang Jabatan Notaris, tesis, Magister Kenotariatan Universitas Gajah Mada, Yogyakarta, 2014.

Manuaba, Ida Bagus Paramaningrat, Prinsip Kehati-hatian Notaris dalam Membuat Akta Autentitk, tesis, Program Magister Kenotariatan Fakultas Hukum Universitas Udayana, 2017.

\section{Internet}

"Waspadai Tuntutan Pidana yang Mungkin Dihadapi Notaris dalam Bertugas" https: / / www.ucnews.id/news/Waspadai-Tuntutan-Pidana-yangMungkin-Dihadapi-Notaris-dalam-Bertugas/4072341047767155.html, diakses tanggal 23 September 2018. 